\section{Public spending cuts threaten UK universities}

THE UK government is on the brink of a decision which could be disastrous for the country's universities, according to Sir Alec Merrison, Chairman of the Committee of Vice-Chancellors and Principals. Proposed cuts in funds would almost certainly mean the closure of some departments and even whole universities, he told a press conference last week, and universities would not be able to educate well-qualified home students whose numbers are likely to continue increasing over the next few years.

The CVCP was responding to the government's intention - outlined in a letter from the University Grants Committee to all universities last week to hold the universities' recurrent grant at the 1979-80 level for several years and remove all UK government support for overseas students embarking on their studies on or after the 1980-81 academic year.

Cutting out funds for overseas students would result in a $13 \%$ fall in university income by $1983-84$. The money could only be recovered if large numbers of overseas students were capable of paying their own fee - estimated at $£ 3,500$ each. This is highly unlikely, says the CVCP in a letter to Mark Carlisle, the Education Secretary. Overseas students would have to pay many times more to study in the UK than in other western countries and would therefore go elsewhere. British universities would cease to compete internationally. Some universities would be hit very badly, for example, the University of Manchester Institute of Science and Technology, a third of whose students come from overseas.

The vice-chancellors are concerned that research as well as teaching is bound to suffer. In looking for economies, universities would tend first to cut spending on research equipment. "The whole question of research is considerably at risk", Sir Alec said.

A further problem for universities is uncertainty about the 1979-80 level of funding which is to be used as the base for the recurrent grant until 1983-84. Salaries for university staff have yet to be agreed for the year ending July 1979 and the government has given no assurance that it will meet any increases. The CVCP is also concerned that pegging their future funds at 1979-80 levels will not take account of inflation and pay increases to come in the next few years. Many universities are already having difficulties existing on their funds. Sir Alec's own university, Bristol, ran up a deficit of $£ 500,000$ in an income of $£ 25$ million last year. "I'd be very surprised", he said "if there aren't some institutions that have had to go to the bank already."
OIL 1978

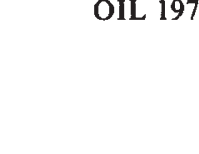

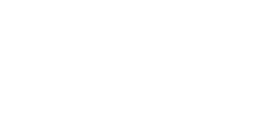

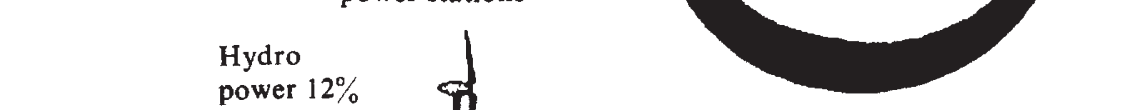

Wind power $5 \%$ 3,700 large wind power stations

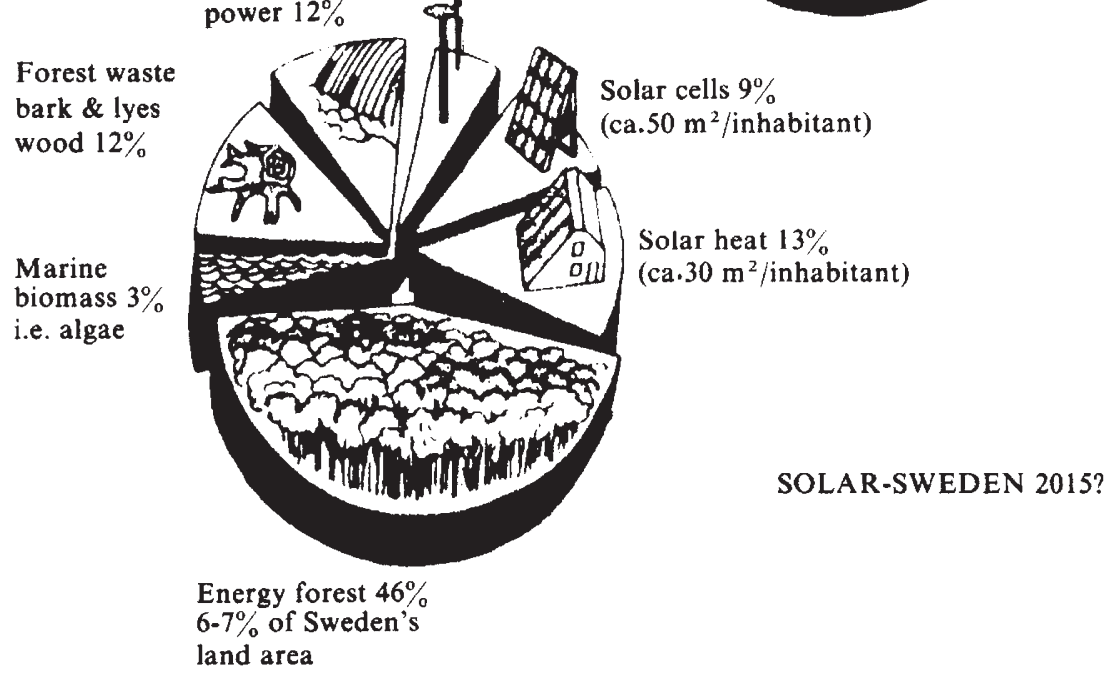

Changing the energy equation: how Sweden's forecasters see the future

\section{Sweden warms to biomass power}

INDEPENDENCE from oil as a source of energy was the basis of a Swedish contribution to a seminar on Technological Forecasting Methodologies recently held by the UN Economic Commission for Europe (ECE). The authors Thomas B Johansson of Lund University, and Peter Steen of the Swedish Research Institute for National Defence, suggest that $61 \%$ of the nation's energy could be provided by biomass. Six to seven percent of the country's land area, they propose, would be devoted to energy forests, estimated to yield $46 \%$ of the country's needs; forest waste and wood lyes (pulp effluent) would contribute $12 \%$ and marine biomass $3 \%$. Other contributors would be solar heat $(13 \%)$, conversion through solar cells $(9 \%)$, wind, and hydro-power $(12 \%$ - the same as the current figure).

No mention however is made of methane from the conversion of urban waste, a resource already used in some other north European countries. The figures are contrasted with those of the present system, which relies on oil for $72 \%$ of the country's needs, hydropower for $12 \%$, woodwaste $8 \%$, coal and coke and nuclear $4 \%$. Neither coke nor nuclear appears in the 2015 forecast, which is said to allow for "moderately increased efficiency" and "twice the production of goods and services compared with today".
The authors have assumed that "the energy system should be fully implemented in the year 2015", and have calculated backwards the necessary rate of expansion. This gives $50 \%$ implementation from renewable resources by the year 2000 . The rate they estimate is less than that estimated by the Swedish National Board for Energy Source Development. At the same time the cost of the proposed system is "not in conflict with production levels assumed for the whole economy" while it is based on a continued increase in labour productivity.

But there are difficulties. For example, there are to be major political and economic issues with regard to land-use policy and the capital market, since the proposals would require more land area and are more capital extensive than the present energy system. However, Sweden is already very advanced in research on energy plantations, making use of selected strains of various tree species grown on a short rotation system and giving yields comparable to those found in the tropics.

Two German papers at the seminar, however, estimated that solar energy would contribute only $5 \%$ of all energy by the year 2000 . They paid little attention to the indirect uses of solar energy through biomass conversion or the better use of wood and wood-products. However, several other ECE meetings have been 
devoted to the energy aspects of the forest industries. At one it was indicated that the energy input of the industry itself to pulp and paper manufacture ranged from $5-35 \%$ in different countries, with a very much lower figure ( $5 \%$ only) for the input to the mechanical processing side. Sweden, again, is a leader in examining how these figures could be improved by more efficient use of forest waste: one recent estimate gives 50 million $\mathrm{m}^{3}$ of residues consumable as fuel if not partially recovered for other processing, for every 60 million $\mathrm{m}^{3}$ of commercial round wood produced annually.

Again, in Finland it is estimated that small sized wood, stump/root systems and other forest waste could provide 3.6 million tons oil equivalent a year, with another 0.8 mtoe depending on the market for certain hardwood products. Timber industries, faced with rapidly rising energy costs from conventional sources, are examining new ways of using their own waste products, either by direct combustion or through conversion into gas or liquid fuels. An advantage is that wood is not carcinogenic and is low in both nitrogen and sulphur. According to one ECE reort, forest product industries can and should become energy independent soon, later supplying surplus biomass to other users.

Peter Collins

\section{Poland calls for wider research cooperation .}

International cooperation at every level from pure academic research to industrial design and implementation - is essential if a country's research potential is to develop to its full capacity. So Jan Mazurkiewicz, Director of 'Export and Economic Relations with Abroad' of the Polish Ministry of the Machine Industry told Nature recently. He was summarising the significance of "Poland's Technology, 1979"' a series of seminars and technical exhibitions held last week in London, Manchester, Birmingham, and Coventry.

The close integration of research with industry is a basic feature of Polish planning. It was perhaps less familiar to some of the British participants, who seemed a little at a loss as to whether to expect learned discourses or sales promotion talks. For the event, sponsored on the British side by the Chambers of Commerce of the host cities, was the reciprocal or a similar British week in Warsaw last autumn, and represents one of the more positive results of Poland's large trade gap with Britain.

If trade between the two countries is to increase - and the state of the Polish economy makes this highly desirable some new form of cooperation must be found. Recently, joint research and development projects, culminating in joint production for a third market, has increasingly been proposed on both sides as an attractive solution.

Any viable proposal for joint projects presupposes, that both sides know what the other has to offer. "A symposium means the meeting of people with like interests", Mr Mazurkiewicz explained. "So we chose our team very carefully - a couple of academicians, a test pilot, two plant engineers, an administrator, and so on. We looked for a good variety, for people with open minds, with whom there could be a point of contact."

The subjects, which ranged from medical electronics to machine tools and from computer software to agricultural aviation, were selected by the Polish side as fields where they felt they had something valuable to offer. Inevitably, in the discussion of any cooperation projects, sooner or later the problem of strategic military embargoes crept in. These, however, were peripheral, and in one instance, Jacek Szporko of "Unitra-
Elektron" joked that the strategic embargo of the early 1960s had indirectly led to Poland's present expertise in semiconductor technology.

The close links between Polish research and industry meant that the Polish team could include lecturers of considerable international standing. Andrzej Radziminski (software and computer services) is a member of the Advisory Committee for Informatics Projects of the International Bureau for Informatics $\mathrm{Dr}$ Tadeusz Zak, who lectured on the Polish technological equipment industry, is a member of the Comecon Plenipotentiary Committee for Corrosion Problems, and Dr Halina Leszcynska (industrial sulphur processing) was closely involved in the development of granulated sulphur. This is free of the health and environmental hazards that had been closing more and more ports throughout the world to sulphur in its traditional powder form.

Dr Leszczynska is a member of the Committee of Chemical Sciences of the Polish Academy of Sciences, and, as such, represented a field which, she said, is always in the "top three places of research investment", due to its "importance in the

national economy'. She was particularly optimistic about the outcome of the week. "There are already a lot of people doing joint research at post-graduate level", she said. "What this week has done is to provide new direct contacts at the development level."

Several members of the Polish team, in informal discussions, suggested that joint industrial and development projects should ideally be based on truly joint research, rather than bringing together the results of research at a late stage.

Although the symposium, was slanted rather towards the industrial end of the research and development strectrum, the lectures from time to time revealed interesting sidelights on Polish research structure which would undoubtedly have to be taken into account in the planning of any joint research. Who would have guessed - until test pilot Wieslaw Mercik pointed it out - that the Warsaw Aviation Institute does no work at all on whole-body helicopter design, but is simply responsible for testing the aerodynamic and performance characteristics of designs produced in the factory design offices?

Vera Rich

\section{- . . while the East Germans must wait for a trade agreement first}

THE German Democratic Republic, which celebrated its 30 th anniversary recently, is a country where, according to Dr Lutz Buschendorf, First Secretary (Science and Technology) of the GDR Embassy in London, every single worker is to some extent involved in science. Unfortunately, he said, so far scientific cooperation between the UK and the GDR has not developed to the extent one might have hoped. The reason, from the East German point of view, is the "unwillingness" of the UK to sign a cooperation agreement in which science and technology would not be linked to trade.

At present, technological cooperation comes under the Joint Agreement, originally drawn up in 1973, in which the British side comes under the aegis of the Department of Trade. This is the standard situation for all UK cooperation deals with Eastern Europe. The involvement with trade has a two-fold basis. Firstly, from the beginning, the UK felt that if the agreements were to bring genuinely mutual benefits, then some kind of counter-trade would be needed to off-set a predominantly one way, West to East flow of technology. Secondly, the administration of the agreements by the Department of Trade (via a special technology unit) is a result of the way the ministry of technology was dismantled.

To the East Germans, however, the link with trade constitutes a major psychological block. When the then UK Secretary of State for Trade, Edmund Dell, visited the GDR some three years ago, he stressed that under existing economic conditions the trade turn-over between the UK and the GDR could well be doubled. Some Germans seem to have taken this as a direct challenge to their thesis that increased scientific and technological cooperation should pre-date any major expansion of trade. "We want to make 